\title{
The Effort to Reduce Vasovagal Reaction and Abdominal Pain During Stapled Hemorrhoidopexy
}

\author{
Hyeonseok Jeong \\ Department of Surgery, Busan Hangun Hospital, Busan, Korea
}

\section{See Articles on Page 344-348}

In 1998, Dr. Longo introduced a hemorrhoid surgical procedure using a circular stapler suturing device [1]. Since then, stapled hemorrhoidopexy $(\mathrm{SH})$ has been widely done with the advantages of less pain and faster recovery than conventional hemorrhoid surgery [2]. But as time goes by, the disadvantages of SH have been reported. The most common problem is recurrence after a long time after SH $[3,4]$. In addition, $\mathrm{SH}$ specific complications such as life-threatening sepsis due to rectal perforation and rectovaginal fistula were reported [5-7]. And common hemorrhoid complications such as stenosis and fecal incontinence were also reported [8, 9]. This complication is major and serious problem, and many reports and studies have been made due to difficulties in treatment. Fortunately, these complications are not common [8].

However, empirically, there are complications that are experienced at least more than once during $\mathrm{SH}$ surgery. It is the vasovagal reaction (VVR; nausea, diaphoresis, and syncope) and abdominal pain. Patients usually notice the problems when the operator closes stapler device and fire stapler handle. In general, hemorrhoidectomy is a minor surgery. Therefore, it could be done in small hospitals or clinics where manpower or equipment are not abundant. In these places, it can be very challenging if a patient loses consciousness with VVR or blood pressure drops during surgery. Few studies have reported the prevalence or severity of these problems, which may be because most of them recover without special treatment.

Most studies about hemorrhoid and pain are the results of using

Correspondence to: Hyeonseok Jeong, M.D.

Department of Surgery, Busan Hangun Hospital, 1 Chungnyeol-daero 348beon-gil, Dongnae-gu, Busan 47889, Korea

Tel: +82-51-580-2824, Fax: +82-51-580-2753

E-mail: mdlonelywolf@gmail.com

ORCID: https://orcid.org/0000-0003-3315-8405

(c) 2020 The Korean Society of Coloproctology

This is an open-access article distributed under the terms of the Creative Commons Attribution NonCommercial License (https://creativecommons.org/licenses/by-nc/4.0) which permits unrestricted noncommercial use, distribution, and reproduction in any medium, provided the original work is properly cited. lidocaine, nitroglycerin, calcium channel blocker, etc., to relieve anal pain after surgery $[10,11]$. There have been several studies on VVR and abdominal pain that can occur during hemorrhoidectomy and band ligation. Kim et al. [12] reported effect of lidocaine injection on lower rectal submucosa during hemorrhoidectomy. VVR was presented in 9 patients of 100 patients during conventional hemorrhoidectomy. Pain and VVR during surgery were reduced significantly in the lidocaine injection group compared to the control group. In another randomized controlled trial, they compared band ligation with local anesthesia and without (control). They checked vasovagal symptoms at the time of banding and pain scores at the conclusion of procedure, after 15 minutes, and on leaving the clinic. Vasovagal symptom was presented in 12 patients of 80 patients. The pain score was significantly lower compared to the control group, but there was no significant difference in vasovagal symptoms [13].

In the $\mathrm{SH}$, there are few papers about the prevalence or prevention method of VVR that occurs during surgery. Cho et al. [14] reported a randomized control trial of incidence VVR and the effect of lidocaine injection during $\mathrm{SH}$. A total of 111 patients were included in this study and 20 patients had low abdominal pain during $\mathrm{SH}$. And there were VVR in 5 patients during procedure. The lidocaine injection group experienced lesser lower abdominal pain and dizziness than the control group. This study has some limitations including a small number size. But it is impressive to check of the prevalence of VVR and lower abdominal pain during SH. And an attempt to prove the effect of lidocaine use, which is known empirically, can be considered meaningful.

Usually, patients who underwent $\mathrm{SH}$ notice low abdominal pain when stapler device is closed. Abdominal pain or VVR may be associated with a pulled mucosa in process of $\mathrm{SH}$. In this study, the results were not compared according to the surgical method [14]. However, in the case of partial SH, selectively pure-string sutures were done to only the hemorrhoidal tissues preserving normal tissue [15]. So the degree of mucosa is smaller than that of circular SH. If studies are conducted based on the difference between partial SH and circular SH, much information may be taken about VVR and abdominal pain during $\mathrm{SH}$.

$\mathrm{SH}$ is widely used as a surgical method of hemorrhoids. And it 
is an important issue to operate the patient safely and comfortably. Many studies are conducted to prevent and resolve only severe complications of SH. It is also important to study VVR or abdominal pain that may occur during $\mathrm{SH}$. And the mechanism of VVR and low abdominal pain during surgery is unclear. To resolve this problem and prevent VVR and lower abdominal pain, more research and studies are needed to be done.

\section{CONFLICT OF INTEREST}

No potential conflict of interest relevant to this article was reported.

\section{REFERENCES}

1. Longo A. Treatment of hemorrhoidal disease by reduction of mucosa and hemorrhoidal prolapse with a circular stapler suturing device: a new procedure. In: Montori A, Lirici MM, Montori J; European Association for Endoscopic Surgery. Proceeding of the 6th World Congress of Endoscopic Surgery; 1998 Jun 3-6; Rome, Italy. Bologna: Monduzzi Editore; 1998. p. 777-84.

2. Pavlidis T, Papaziogas B, Souparis A, Patsas A, Koutelidakis I, Papaziogas T. Modern stapled Longo procedure vs. conventional Milligan-Morgan hemorrhoidectomy: a randomized controlled trial. Int J Colorectal Dis 2002;17:50-3.

3. Schneider R, Jäger P, Ommer A. Long-term results after stapled hemorrhoidopexy: a 15-year follow-up. World J Surg 2019;43: 2536-43.

4. Sturiale A, Fabiani B, Menconi C, Cafaro D, Fusco F, Bellio G, et al. Long-term results after stapled hemorrhoidopexy: a survey study with mean follow-up of 12 years. Tech Coloproctol 2018;22: 689-96.

5. Liekens E, van Sprundel F, Thiessen F, Pirenne Y. Martius flap reconstruction for rectovaginal fistula after stapled hemorrhoidopexy (Longo operation): a case report. Int J Colorectal Dis 2019;
34:1619-23.

6. Molloy RG, Kingsmore D. Life threatening pelvic sepsis after stapled haemorrhoidectomy. Lancet 2000;355:810.

7. Park YJ. Pneumoretroperitoneum after procedure for prolapsed hemorrhoid. Ann Coloproctol 2013;29:256-8.

8. Mlakar B, Kosorok P. Complications and results after stapled haemorrhoidopexy as a day surgical procedure. Tech Coloproctol 2003;7:164-8.

9. Schmidt J, Dogan N, Langenbach R, Zirngibl H. Fecal urge incontinence after stapled anopexia for prolapse and hemorrhoids: a prospective, observational study. World J Surg 2009;33:355-64.

10. Mari FS, Nigri G, Dall'Oglio A, Cosenza UM, Milillo A, Terrenato I, et al. Topical glyceryl trinitrate ointment for pain related to anal hypertonia after stapled hemorrhoidopexy: a randomized controlled trial. Dis Colon Rectum 2013;56:768-73.

11. Perrotti P, Dominici P, Grossi E, Cerutti R, Antropoli C. Topical nifedipine with lidocaine ointment versus active control for pain after hemorrhoidectomy: results of a multicentre, prospective, randomized, double-blind study. Can J Surg 2010;53:17-24.

12. Kim TS, Kim DS, Kang YS, Jung SY, Cho HJ, Lee DH. Effect of lidocaine injected on lower rectal submucosa during hemorrhoidectomy under caudal anesthesia. J Korean Soc Coloproctol 1998; 14:85-9.

13. Kwok HC, Noblett SE, Murray NE, Merrie AE, Hayes JL, Bissett IP. The use of local anaesthesia in haemorrhoidal banding: a randomized controlled trial. Colorectal Dis 2013;15:487-91.

14. Cho KJ, Hwang DY, Lee HJ, Hyun KH, Kim TJ, Park DH. Prospective comparative analysis of the incidence of vasovagal reaction and the effect of rectal submucosal lidocaine injection in stapled hemorrhoidopexy: a randomized controlled trial. Ann Coloproctol 2020;36:344-8.

15. Jeong H, Hwang S, Ryu KO, Lim J, Kim HT, Yu HM, et al. Early experience with a partial stapled hemorrhoidopexy for treating patients with grades III-IV prolapsing hemorrhoids. Ann Coloproctol 2017;33:28-34. 